\title{
A Guiding Program to Improve the Feeling of Happiness for Pre-Service Kindergarten Teachers
}

\author{
Dr Whereen Nashaat Hamada \\ Faculty of Education- Tanta University
}

\begin{abstract}
This document gives formatting instructions for authors preparing papers for publication in the journal. Authors are encouraged to prepare manuscripts directly using this template. This template demonstrates format requirements for the present study aims at testing the effectiveness of the suggested guiding program to improve the feeling of happiness for pre-service kindergarten teachers. The descriptive study sample was formed of (350) students from faculty of education, Tanta University, whereas the experimental study sample included (10) students. Also, a subsequent and previous measure was done. The study tools were a measure the feeling of happiness and suggested guiding programed prepared by the researcher. The study findings showed differences with statistical significance among arithmetic means of the experimental group grades in the previous and subsequent measure related to the feeling of happiness in favor of the subsequent measure. Meanwhile, the subsequent measure of the feeling of happiness witnessed no differences with statistical significance in the arithmetic means of the experimental group grades.
\end{abstract}

Keywords: Guiding programs, feeling of happiness, pre-service kindergarten teachers

\section{Introduction}

The feeling of happiness is a cognitive phenomenon as a result of a deliberate assessment of the quality of life of the individual and his satisfaction with it according to the criteria it sets [1]. [2] indicates that happiness is a feeling of moderation in the mood and purposeful life and the high level of the individual's feeling of satisfaction with his life, as he is exposed to him from the sources of personal happiness represented in public health care, selfsatisfaction and appreciation, and the economic level, and the sources of social happiness represented in communication and interaction with Others, social relations and social support While [3]. Believes that happiness is the individual possessing a certain type of positive attitude towards his life, which contains a cognitive and emotional component as well as the degree to which the individual judges the overall quality of his life positively, [4]

.indicates that happiness is a multidimensional concept that consists of several basic parts and is the emotional side where the happy individual shows this in his actions and feelings during his reaction to life events, the social aspect and the happy individual enjoys good social relations with Others and cooperate with them and can obtain social support and support from others and finally the cognitive side and it appears in the provisions related to satisfaction with life where the happy individual processes information and data and explains it in a special way so that in the end he can have a feeling of happiness, optimism and hope, [5] tried to improve the feeling of happiness and reduce the severity of depression among university students through a behavioural knowledge program. The students in the experimental group were higher than the students of the control group, in the follow-up period after 8 months, As for [6]. He conducted a study to identify the relationship between happiness and mental health among university students. The sample of the study consisted of (100) male and female students from the university students, as it consisted of females (70), males (30), and the results of his study revealed a statistically significant relationship between happiness and mental health, and also found that there are no major differences between The two sexes (male - female) are at the level of happiness and mental health of university students, and the socio-demographic 
variables have no role in the students 'happiness and wellbeing. degrees for related samples of the previous and subsequently measure as the( Table. 1 ) shows

\section{Methodology}

In the recent study, the researcher tries to design a multitechnical guiding program to help to Improve the feeling of happiness for pre-service kindergarten teachers . The study included students from Tanta University representing general frame of the society from which a lot of students from faculty of education were chosen to form the study sample. After reading the previous researches in that field, the program was formed from the guiding aim, procedural aims of the program, the need to the program, steps of guiding program, mechanism, techniques used in the program, services offered by the program and executive procedures for every and each stage in the program . The feeling of happiness scale was used in that program, which is considered a tool to assess the feeling of happiness among young men and women students of the university, and the scale contains 40 words to measure three dimensions, and the number of phrases that measure after emotional balance reached 14 words, while the phrases that measure after physical and mental health It is (12 phrases), while the phrases that measure after being satisfied with life are (14 phrases). The responses were evaluated on a triple runway starting with yes $=3$, to some extent $=2$, not $=1$, according to the direction of the phrase, provided that negative phrases take the opposite of this gradient, and thus the overall degree of the measure of happiness ranges from (40 - 120) degrees. Reliability of the measure was tested via agreement percentage of a group of ten specialists in psychology, kindergarten and psychological health. Most phrases were agreed on with a percentage exceeding $80 \%$. Some phrases were amended according to specialists' opinions. Interior harmony of the measure items was verified. To illustrate, values of correlation coefficients $(\mathrm{N}=106)$ rated from $(0,74)$ to $(0,88)$. All correlation coefficients of the items had significance at level of $(0,01)$. An (SPSS) program was used to get the study results by using Pearson correlation coefficients to know the relationship between the study variables. Also, Wilcoxon test was used in the research to show the significance and differences between arithmetic means of grades of the previous and subsequent measures in a hand and the subsequent and following up measures in another hand.

\section{Results}

After verifying methodology and validity of the premise, there were differences with statistical significance between arithmetic means of the experimental group grades in the previous and subsequently measure on the scale of the feeling of happiness (Emotional balance, Physical and mental health, Satisfaction with life and total degree) at the side of the subsequently measure because of using the practical program and using the researcher to Wilcoxon test to measure the differences between means of measure
Table (1) Wilcoxon test to measure the differences between means of measure degrees for related samples of the previous and subsequently measure.

\begin{tabular}{|c|c|c|c|c|c|c|}
\hline Dimensions & Measures & $\begin{array}{c}\text { Arithmetic } \\
\text { Mean }\end{array}$ & $\begin{array}{c}\text { Means of } \\
\text { negative } \\
\text { grades }\end{array}$ & $\begin{array}{c}\text { Means } \\
\text { of } \\
\text { positive } \\
\text { grades }\end{array}$ & $\begin{array}{c}\text { Values } \\
\mathrm{Z}\end{array}$ & Sig \\
\hline \multirow{2}{*}{$\begin{array}{l}\text { Emotional } \\
\text { balance }\end{array}$} & Pre & 10 & \multirow[t]{2}{*}{.00} & \multirow[t]{2}{*}{5.50} & \multirow[t]{2}{*}{2.80} & \multirow{2}{*}{$\begin{array}{c}0.00 \\
5\end{array}$} \\
\hline & Post & 42.4 & & & & \\
\hline \multirow{2}{*}{$\begin{array}{l}\text { Physical and } \\
\text { mental health }\end{array}$} & Pre & 9.6 & \multirow[t]{2}{*}{.00} & \multirow[t]{2}{*}{5.50} & \multirow[t]{2}{*}{2.80} & \multirow{2}{*}{$\begin{array}{c}0.00 \\
5\end{array}$} \\
\hline & Post & 37.7 & & & & \\
\hline \multirow{2}{*}{$\begin{array}{l}\text { Satisfaction } \\
\text { with life }\end{array}$} & Pre & 10 & \multirow[t]{2}{*}{.00} & \multirow[t]{2}{*}{5.50} & \multirow[t]{2}{*}{2.82} & 0.00 \\
\hline & Post & 42.2 & & & & 5 \\
\hline \multirow[t]{2}{*}{ Total grade } & Pre & 19.6 & \multirow[t]{2}{*}{.00} & \multirow[t]{2}{*}{5.50} & \multirow[t]{2}{*}{2.80} & 0.00 \\
\hline & Post & 80.2 & & & & 5 \\
\hline
\end{tabular}

\section{Discussion}

Pre results show that the guiding program has an effect on the feeling of happiness because of the use of good ways and techniques which were proven to be effective in a lot of studies and researches. Focusing on the cognitive variables, the guiding program tried to change some beliefs and thoughts or at least to amend deviant behaviors and replacing them with correct ones which lead to making cognitive and conductive changes for the study sample. Depending on psychological learning sessions, the guiding program tried to increase students' awareness of the feeling of happiness concept, push them to participate and to warn against wrong concepts. Also, the guiding program helped pre-service kindergarten teachers to achieve emotional balance, physical and mental health, and life satisfaction.

\section{Conclusion}

Feeling happy is essential to help individuals achieve emotional balance, physical and mental health, and life satisfaction; the thing which leads to making interaction with the surrounding environment and drawing its dimensions to make it proper. Students in universities are considered suitable persons for feeling of happiness due to their psychological and emotional growth in addition to having good abilities to do so, so they should be treated as an effective factor in any society.

\section{References}

[1] Veenhoven , R. ( 2006 ) . How Do We Assess How Happy We Are? Tenets, implications and tenability of three theories. Paper presented at conference on 'New Directions in the Study of Happiness: United States and International Perspectives', University of Notre Dame, USA, October 22-24

[2] Al-Qatawi , S (2014). Feeling of psychological happiness and its relationship to some variables among a sample of the hearing impaired, Arab studies in Education and Psychology, p (25), pp (1346). 
[3] Aboalshamat, K., Alsiyud, A. O ., Al-Sayed, R .A., Alreddadi , R .S ., Faqiehi , S. S. \& Almehmadi, S.A.( 2018 ) . The relationship between resilience, happiness, and life satisfaction in dental and medical students in Jeddah, Saudi Arabia. Niger J Clin Pract. 21(8), 1038-1043.

[4] Nemati , S \& Maralani , F.M ( 2016 ). The Relationship between Life Satisfaction and Happiness: The Mediating Role of Resiliency . International Journal of Psychological Studies, V ( 8 ) N ( 3 ) , PP ( 194-201).

[5] Sánchez-Hernández , O., Méndez , F.X., Ato , M. \& Garber , J. ( 2019 ). Prevention of Depressive Symptoms and Promotion of Well-being in Adolescents: A Randomized Controlled Trial of the Smile Program . anales de psicología / annals of psychology. V ( 35 ) N ( 2 ), PP ( 225 - 232 ).

[6] Shafiq , S , Naz , R.A., Ansar , M , Nasrulla , T , Bushra , M \& Imam , S ( 2015 ). Happiness as Related to Mental Health among University Students - International Journal of Humanities and Social Science, V ( 5 ) N ( 9 ), PP ( $124-132$ ).

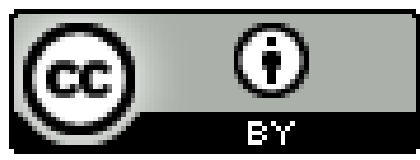

